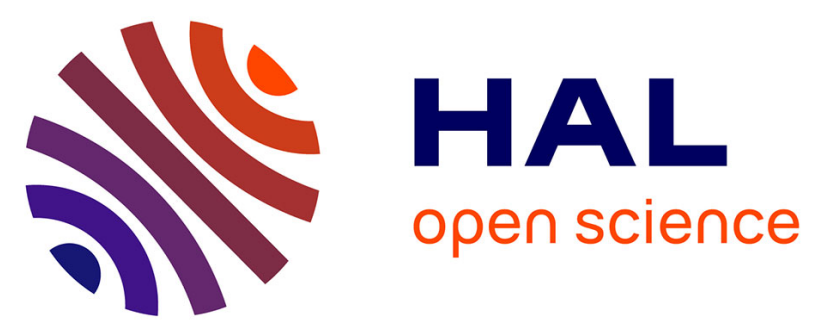

\title{
Atmospheric methane during the last four glacial-interglacial cycles: Rapid changes and their link with Antarctic temperature
}

M. Delmotte, J. Chappellaz, E. Brook, P. Yiou, J.M. Barnola, C. Goujon, D. Raynaud, V. Lipenkov

\section{To cite this version:}

M. Delmotte, J. Chappellaz, E. Brook, P. Yiou, J.M. Barnola, et al.. Atmospheric methane during the last four glacial-interglacial cycles: Rapid changes and their link with Antarctic temperature. Journal of Geophysical Research, 2004, 109 (D12), 10.1029/2003JD004417 . hal-03131001

\section{HAL Id: hal-03131001 \\ https://hal.science/hal-03131001}

Submitted on 4 Feb 2021

HAL is a multi-disciplinary open access archive for the deposit and dissemination of scientific research documents, whether they are published or not. The documents may come from teaching and research institutions in France or abroad, or from public or private research centers.
L'archive ouverte pluridisciplinaire HAL, est destinée au dépôt et à la diffusion de documents scientifiques de niveau recherche, publiés ou non, émanant des établissements d'enseignement et de recherche français ou étrangers, des laboratoires publics ou privés. 


\title{
Atmospheric methane during the last four glacial-interglacial cycles: Rapid changes and their link with Antarctic temperature
}

\author{
M. Delmotte, ${ }^{1,2}$ J. Chappellaz, ${ }^{1}$ E. Brook, ${ }^{3}$ P. Yiou, ${ }^{4}$ J. M. Barnola, ${ }^{1}$ C. Goujon, ${ }^{1}$ \\ D. Raynaud, ${ }^{1}$ and V. I. Lipenkov ${ }^{5}$ \\ Received 4 December 2003; revised 6 March 2004; accepted 30 March 2004; published 24 June 2004.
}

[1] Atmospheric methane $\left(\mathrm{CH}_{4}\right)$ recorded in Antarctic ice cores represents the closest ice proxy available for Greenland temperature changes beyond times when Greenland climate records are available. The record over four climatic cycles from the Vostok ice core offers the opportunity to study the phase relationship between Greenland and Antarctic climate changes through detailed $\mathrm{CH}_{4}$ profiles. Combining American and French analytical efforts, we have improved the time resolution of the existing $\mathrm{CH}_{4}$ record from Petit et al. [1999]. Spectral analyses reveal high- and low-frequency variability (including a strong precessional component). The phase relationship between $\mathrm{CH}_{4}$ and the Antarctic temperature proxy $(\delta D)$ shows a systematic lag of $\mathrm{CH}_{4}$ versus temperature by $1100 \pm 200$ years, on long timescales $(50-400 \mathrm{kyr})$ and a more complex behavior over shorter timescales (i.e., $\leq 25 \mathrm{kyr}$ ), suggesting that Dansgaard/Oeschger-type of climatic variability and associated interhemispheric linkage are robust features of late Quaternary climate. INDEX TERMS: 0325 Atmospheric Composition and Structure: Evolution of the atmosphere; 1610 Global Change: Atmosphere (0315, 0325); 1615 Global Change: Biogeochemical processes (4805); 3339 Meteorology and Atmospheric Dynamics: Ocean/atmosphere interactions (0312, 4504); KEYWORDS: climate, atmospheric methane, ice core

Citation: Delmotte, M., J. Chappellaz, E. Brook, P. Yiou, J. M. Barnola, C. Goujon, D. Raynaud, and V. I. Lipenkov (2004), Atmospheric methane during the last four glacial-interglacial cycles: Rapid changes and their link with Antarctic temperature, J. Geophys. Res., 109, D12104, doi:10.1029/2003JD004417.

\section{Introduction}

[2] In the context of global climate change, the study of greenhouse gases such as carbon dioxide $\left(\mathrm{CO}_{2}\right)$, methane $\left(\mathrm{CH}_{4}\right)$, and other biogenic gases is of major interest [Intergovernmental Panel on Climate Change, 2001]. Records of atmospheric trace gas mixing ratios over tens of millennia from ice cores allow to better document the natural cycles of these gases and to identify mechanisms and interactions responsible for climate change and/or variability. They are unique complements to direct atmospheric measurements (covering only the last 50 years or so) and numerous studies over the past 2 decades have demonstrated that ice cores (in particular in Antarctica) faithfully record the atmospheric history of $\mathrm{CH}_{4}$ and other trace gases [Etheridge et al., 1996, 1998]. These studies have contributed significantly to our understanding of climate and of the biogeochemical cycles that control the level of various trace gas species in

\footnotetext{
${ }^{1}$ Laboratoire de Glaciologie et Géophysique de l'Environnement, CNRS-UJF, St. Martin d'Hères, France.

${ }^{2}$ Now at Laboratoire des Sciences du Climat et de l'Environnement, CNRS-CEA, Gif sur Yvette, France.

${ }^{3}$ Department of Geology, Washington State University, Vancouver, Washington, USA.

${ }^{4}$ Laboratoire des Sciences du Climat et de l'Environnement, CNRSCEA, Gif sur Yvette, France.

${ }^{5}$ Arctic and Antarctic Research Institute, St. Petersburg, Russia.
}

Copyright 2004 by the American Geophysical Union.

0148-0227/04/2003JD004417\$09.00 the atmosphere [Berner et al., 1978; Brook et al., 1996; Raynaud et al., 1988].

[3] Here we present a refined high-resolution record of atmospheric $\mathrm{CH}_{4}$ from the extended Vostok ice core $\left(78^{\circ} \mathrm{S}\right.$, $106^{\circ} \mathrm{E}, 3488 \mathrm{~m}$ elevation). Initial work conducted at Vostok provided long-term records of $\mathrm{CO}_{2}$ and $\mathrm{CH}_{4}$ [Barnola et al., 1987, 1991; Chappellaz et al., 1990; Jouzel et al., 1993; Raynaud et al., 1988] covering the last 220 kyr. These studies demonstrated a strong relationship between temperature and greenhouse gas $\left(\mathrm{CO}_{2}\right.$ and $\left.\mathrm{CH}_{4}\right)$ variations on glacial-interglacial timescales, with low mixing ratio during cold periods and high mixing ratio during warm ones. The extended $5 \Gamma$ ice core, drilled down to a depth of $3623 \mathrm{~m}$, provides a record of the past four glacial-interglacial cycles ( $420 \mathrm{kyr}$ of atmospheric history [Petit et al., 1999]). We have improved the resolution of the $\mathrm{CH}_{4}$ record, which allows us to discuss $\mathrm{CH}_{4}$ variations on a variety of timescales (typically, 2-100 kyr). We first examine $\mathrm{CH}_{4}$ variability on the glacial-interglacial timescale and then focus in more detail on the shorter-term variability. These observations are used, with the paleotemperature record derived from the $D / H$ ratios in Vostok ice $(\delta D)$, to further constrain the $\mathrm{CH}_{4}$-climate phase relationship during short-term and long-term climate events.

\section{Experimental Procedure and Age Scale}

[4] The high-resolution $\mathrm{CH}_{4}$ record from Vostok presented in this paper is based on measurements at more 
than 700 depth levels (more than 1000 individual samples) conducted both at Laboratoire de Glaciologie et Géophysique de l'Environnement (LGGE, Grenoble, France) and at Washington State University (WSU, Vancouver, Washington, USA). $\mathrm{CH}_{4}$ mixing ratios were measured on three different Vostok cores over the last 15 years (core $3 \Gamma$ and $4 \Gamma$ for the upper $2500 \mathrm{~m}$ and $5 \Gamma$ below $2500 \mathrm{~m})$. Depth differences between ice cores were corrected as described by Petit et al. [1999]. The GT4 timescale (Glaciological Timescale 4) represents the reference timescale used in this study (see [Petit et al., 1999] for details). Other timescales proposed more recently and derived from marine chronology tuning [Shackleton, 2000] or inverse modeling [Parrenin et al., 2001] are also used for sensitivity studies. The gas-ice age difference (hereafter $\Delta$ age), due to the fact that air bubbles are trapped around $100 \mathrm{~m}$ below the surface (about 2 to $6 \mathrm{kyr}$ after the surrounding ice was deposited, depending on the time period considered), has been estimated using a firn densification model, including different assumptions summarized in Table 2 [Arnaud et al., 2000; Barnola et al., 1991]. We obtain the gas age by subtracting the $\Delta$ age with values at each depth from the assigned ice ages.

[5] $\mathrm{CH}_{4}$ measurements were conducted in both laboratories using wet extraction procedures previously described [Brook et al., 2000; Chappellaz et al., 1997]. At LGGE, seven samples can be measured during a single run, and each extracted gas sample is measured three times during the run. The final $\mathrm{CH}_{4}$ value arises from a weighted mean of the three measurements [Chappellaz et al., 1997] taking into account their decreasing precision with decreasing gas pressure injected into the gas chromatograph. At WSU a single measurement is made on each extracted gas sample. At each depth, two separate ice sample were systematically measured. In both laboratories, the $\mathrm{CH}_{4}$ sample mixing ratios are calculated using a calibration procedure conducted with a standard gas reference for each set of measurements and corrected for the blank contamination [Sowers et al., 1997]. For consistency with previously published Vostok $\mathrm{CH}_{4}$ data sets [Chappellaz et al., 1990; Petit et al., 1999; Raynaud et al., 1988], the $\mathrm{CH}_{4}$ mixing ratio presented here are set on the LGGE scale, which is $2 \%(\sim 10 \mathrm{ppbv})$ higher than the NOAA scale used at WSU [Sowers et al., 1997]. New tests and calibration conducted at LGGE during this study generally confirm these results. However, mixing ratios measured at WSU are on average higher than those determined at LGGE. The average shift observed between both data sets over the 250-430 kyr period (same depth resolution between the two laboratories) is $17 \mathrm{ppbv}$ after correcting for offset in the calibration scale. A slight standard drift and/or under or over-estimation of the blank in either laboratory may cause the $17 \mathrm{ppbv}$ shift. The consistency between old and new LGGE $\mathrm{CH}_{4}$ measurements leads us to correct the WSU values by subtracting 17 ppbv from the measured mixing ratios. The mean reproducibility on duplicates at WSU is better than \pm 20 ppbv $(2 \sigma)$. At LGGE more than $25 \%$ of the depth intervals were measured at least twice to check the reproducibility of the method, leading to a comparable reproducibility of $\pm 25 \mathrm{ppbv}(2 \sigma)$. In the following, we refer to the mean values when replicate measurements were performed.

\section{High-Resolution Methane Record}

[6] Near the bottom of the Vostok core (about $430 \mathrm{kyr}$, $3320-3330 \mathrm{~m}$, Figure 1) there is an abrupt and large change in the $\mathrm{CH}_{4}$ mixing ratio and $\delta D$ of the ice. This feature described by Petit et al. [1999] and Raynaud et al. [2002] is thought to be a result of flow disturbance of the stratigraphic record and therefore not a true climate signature [Jouzel et al., 1999]. We will thus limit the following discussion to the $\mathrm{CH}_{4}$ record over the upper $3310 \mathrm{~m}$ (426 kyr) of the core.

[7] The mean temporal resolution of the Vostok global $\mathrm{CH}_{4}$ profile has been improved by $30 \%$ compared to the initial published record [Petit et al., 1999], especially over the interglacial period MIS 9 (550 years) and during the Climate Cycle 2 (CC2) and full glacial section of climate cycle 3 (see Table 1 for definitions and resolutions of the different climate cycles). The improved resolution of the record confirms that $\mathrm{CH}_{4}$ levels in interglacial periods MIS $7.5,9$ and 11 do not exceed $\sim 780$ ppbv. This observation confirms the inference, from lower-resolution data, that the current atmospheric $\mathrm{CH}_{4}$ levels $(>1700 \mathrm{ppbv})$ are highly anomalous with respect to the last $420 \mathrm{kyr}$ of atmospheric history.

[8] The overall correlation between $\mathrm{CH}_{4}$ and $\delta D$ longterm records remains but weakens $\left(R^{2}=0.61\right.$ instead of 0.73 with the previous $\mathrm{CH}_{4}$ data set). The rapid jump of $\mathrm{CH}_{4}$ characterizing the second part of the deglaciation appears sharper than previously shown by the lower-resolution record (less than 400 years, or 800 years for termination IV, MIS 9). Last, a high-frequency variability shows up. $\mathrm{CH}_{4}$ fluctuates within the range 350-600 ppbv during glacial periods, with a typical duration of 1.5 to $3 \mathrm{kyr}$ for each rapid event. Most of this $\mathrm{CH}_{4}$ structure is also depicted by the deuterium record.

[9] Such variability has been originally reported from Greenland ice cores (Figure 1) and also at lower resolution from the Vostok, Byrd, Taylor Dome and Dome C cores over the last glacial period [Blunier and Brook, 2001; Blunier et al., 1995; Brook et al., 1996, 2000; Chappellaz et al., 1993a; Flückiger et al., 1999]. Our refined $\mathrm{CH}_{4}$ profile provides for the first time a detailed picture of this high-frequency variability over several climatic cycles.

\section{Spectral Analyses}

[10] We applied a Multitaper Method (MTM) to the $\mathrm{CH}_{4}$ series (after a linear interpolation of the signal at a 100-year resolution) using the MTM-SSA Toolkit (available at www.atmos.ucla.edu/tcd/ssa). The MTM method was retained over other techniques ((Blackmann-Tukey; Maximum Entropy Method) because it has a better spectral resolution and permits two types of statistical tests to differentiate a time series from background noise [Ghil et al., 2002; Mann and Lees, 1996]. Nevertheless, other spectral methods have been tested and give similar results albeit with a lesser resolution (not shown). Sensitivity tests using different averaging procedures and time steps for resampling did not significantly change the results. On the other hand, using other Vostok timescales (e.g., NJS in 


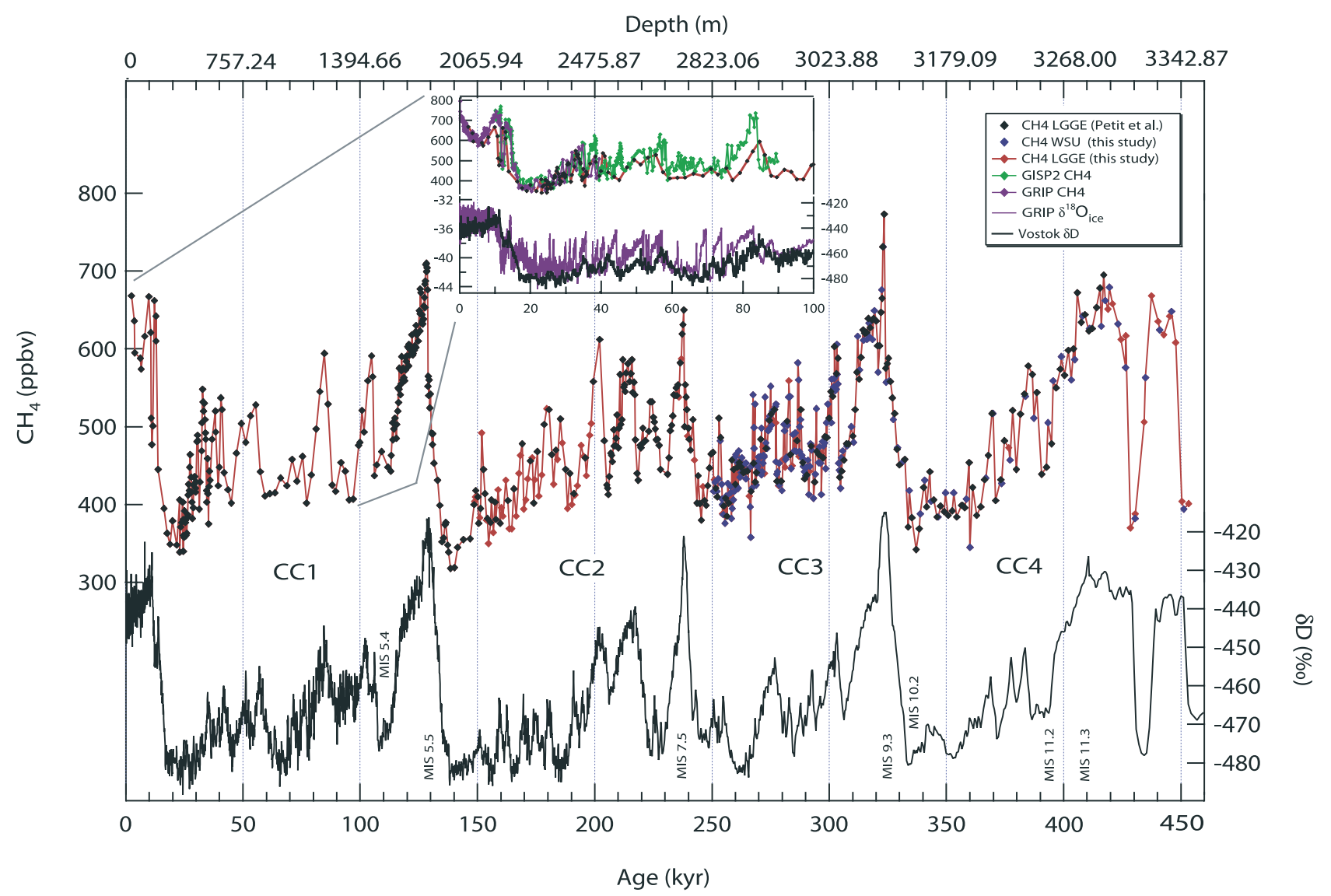

Figure 1. Vostok $\mathrm{CH}_{4}$ and deuterium profiles versus age (lower axis, Glaciological Timescale 4 (GT4) age scale) and depth equivalent (upper axis). The red diamonds are new measurements from Laboratoire de Glaciologie et Géophysique de l'Environnement (LGGE), the blue diamonds are the Washington State University (WSU) new measurements, and the black diamonds are the Petit et al. [1999] data set. In addition, the Greenland Ice Sheet Project 2 (GISP2), the Greenland Ice Core Project (GRIP) $\mathrm{CH}_{4}$, and the GRIP $\delta^{18} \mathrm{O}_{\text {ice }}$ records have been added over the last $80 \mathrm{kyr}$ on the GISP2 timescale for $\mathrm{CH}_{4}$ [Blunier and Brook, 2001] and on the GRIP SS09 timescale for the ice isotopes [Johnsen et al., 1997]. The deuterium data set is from Petit et al. [1999]. The Marine Isotope Stage (MIS) referenced in the text have been reported after Bassinot et al. [1994].

Table 1) can significantly affect spectral properties. This is particularly true for Climatic Cycle 2 (CC2) and Climatic Cycle 3 (CC3) where most dating discrepancies appear (Figures 2 and 3). However, the recurrence of the same peaks at high-frequency bands, being statistically significant whatever the dating used, preclude them from being artifacts.

[11] Apart from the orbital periodicities of 100, 41, 23 and 19 kyr remaining unchanged compared to Petit et al. [1999] (Table 1 and Figure 2), significant peaks around 12 and $10 \mathrm{kyr}$ and even shorter periods (2-7 kyr, see Table 1) appear now. The 10- to $12-\mathrm{kyr}$ period has already been found in climatic records and is thought to be a nonlinear combination from harmonics of the precession band (19$23 \mathrm{kyr}$ ) [Hagelberg et al., 1994; Yiou et al., 1995]. In other words, the Sun passes overhead in the tropics twice a year, so that the Sun is overhead at perihelion every $11 \mathrm{kyr}$. As the tropical regions are particularly sensitive to seasonal insolation changes in the precessional band (affecting the monsoon strength) and are thought to be the major contributing source regions for the $\mathrm{CH}_{4}$ budget [Chappellaz et al., 1993b], it is not surprising to recover this kind of variability within the $\mathrm{CH}_{4}$ record. Similar conclusions were drawn for the last climatic cycle on the Greenland Ice Sheet Project 2 (GISP2) core [Brook et al., 1996].

[12] At the scale of each single climatic cycle, typical periods of high-frequency variability are $9-7 \mathrm{kyr}$ and between 2 and 5 kyr (Table 1), i.e., much similar to those found in earlier studies conducted on the $\mathrm{CH}_{4}$ records from Greenland Ice Core Project (GRIP) and GISP2 cores [Brook et al., 1996; Mazaud et al., 2000; Yiou et al., 2001] for the last glacial period and which were associated with Dansgaard/Oeschger (D/O) events. They reflect millennial-scale $\mathrm{CH}_{4}$ changes that apparently characterize each glacial period investigated here. Indeed the association of the $\mathrm{CH}_{4}$-Greenland isotope variations over the last glacial is not linear; we note that the maximum and/or average amplitude of $\mathrm{CH}_{4}$ changes could vary by more than a factor of 2 or 3 between $\mathrm{D} / \mathrm{O}$ events of similar isotopic amplitude [Brook et al., 1999; Flückiger et al., 2004]. Although the smoothing of atmospheric $\mathrm{CH}_{4}$ fluctuations during gas trapping at Vostok (probably of the order of 500-700 years 


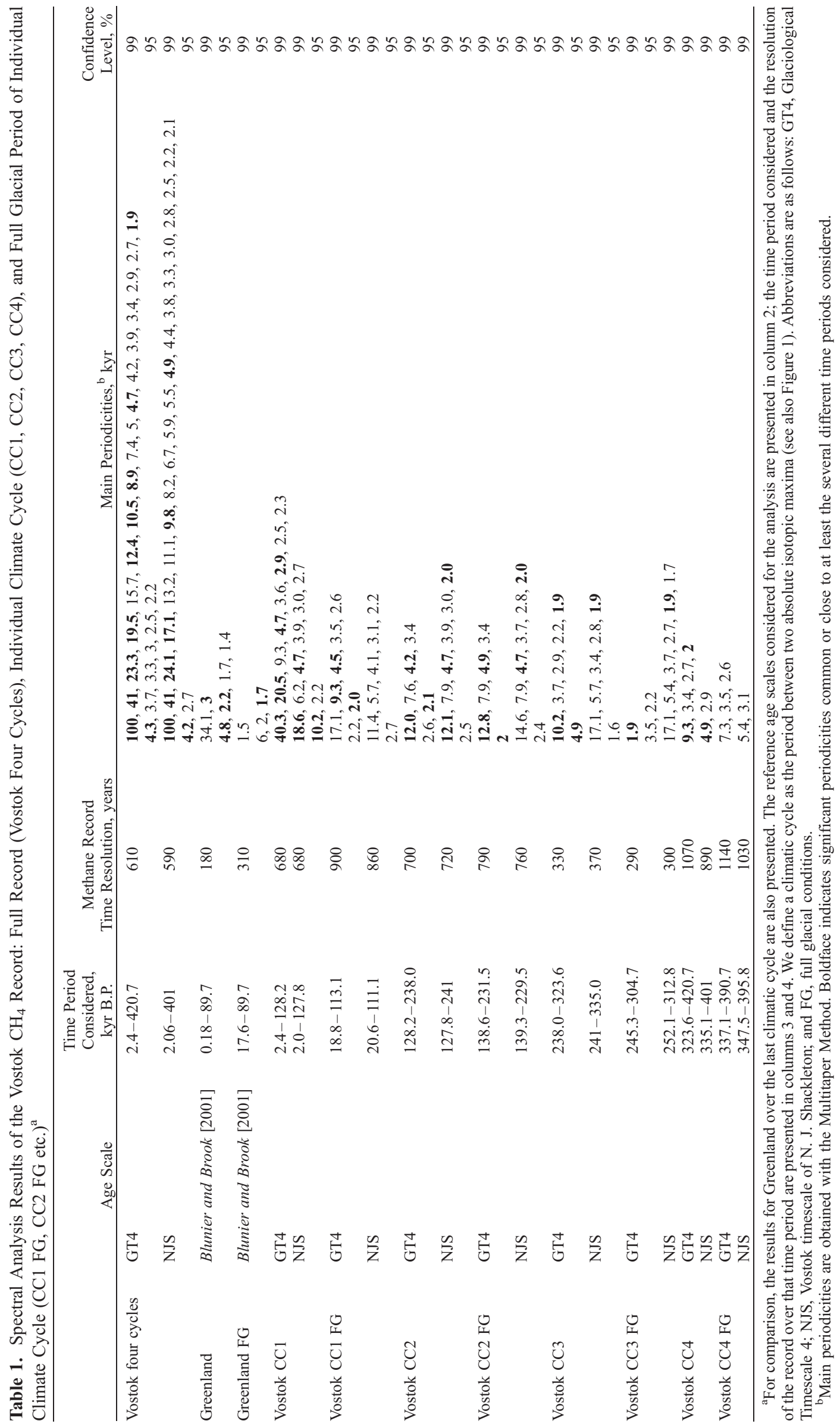




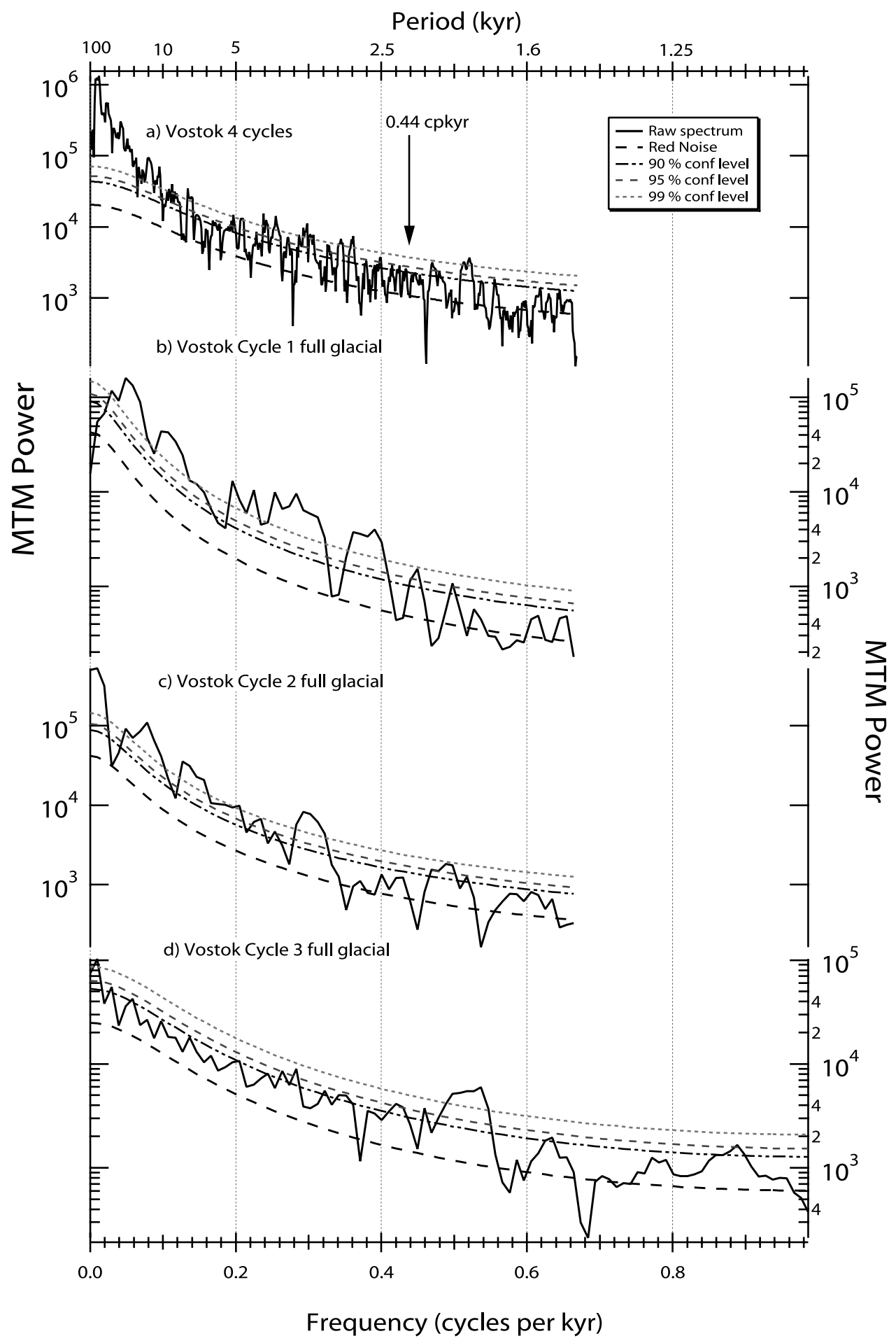

Figure 2. Multitaper Method $\mathrm{CH}_{4}$ power spectra for the GT4 timescale: (a) Vostok complete record (420 kyr); (b) climatic cycle 1, full glacial conditions; (c) climatic cycle 2, full glacial conditions; and (d) climatic cycle 3, full glacial conditions. The power spectra of the complete record, $\mathrm{CC} 1$ and CC2 full glacial conditions, have been limited to the Nyquist frequency (cutting frequency beyond which the results might be unreliable) corresponding to a mean temporal resolution of 750 years. Considering the worse resolution encountered (1140 years) during the full glacial conditions of the fourth climatic cycle would place the Nyquist frequency to $0.44 \mathrm{c} / \mathrm{kyr}$ as illustrated by the arrow on top of Figure 2 . The labels on the top axis represent the periods corresponding to the frequencies shown on the bottom axis. 


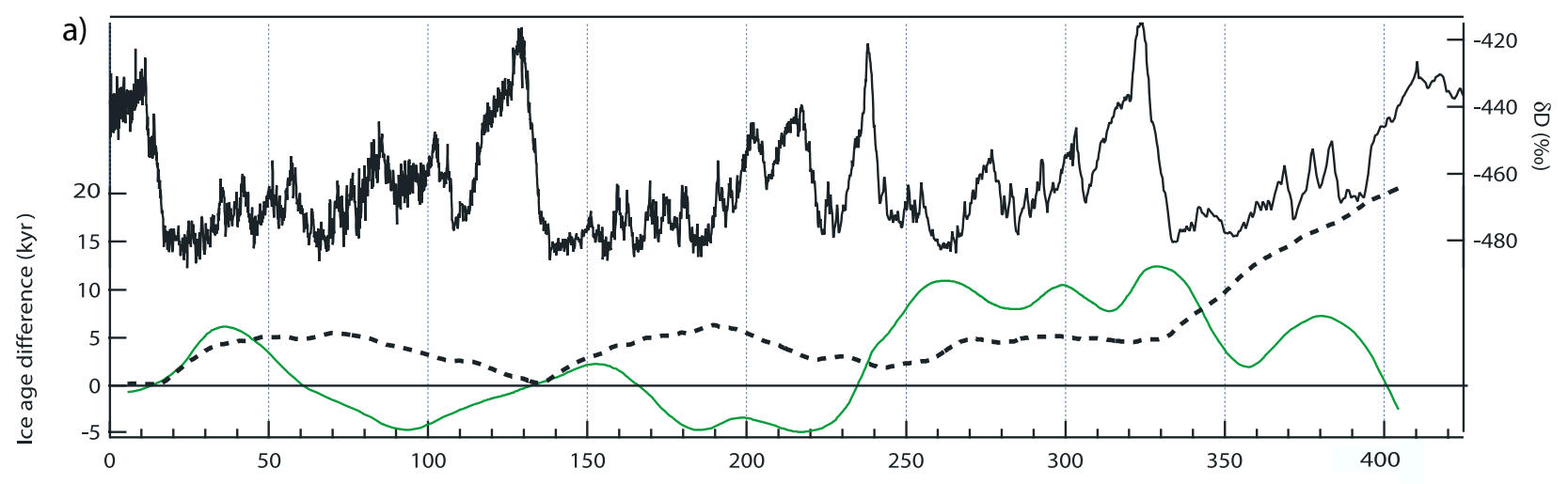

b) Age (kyr)

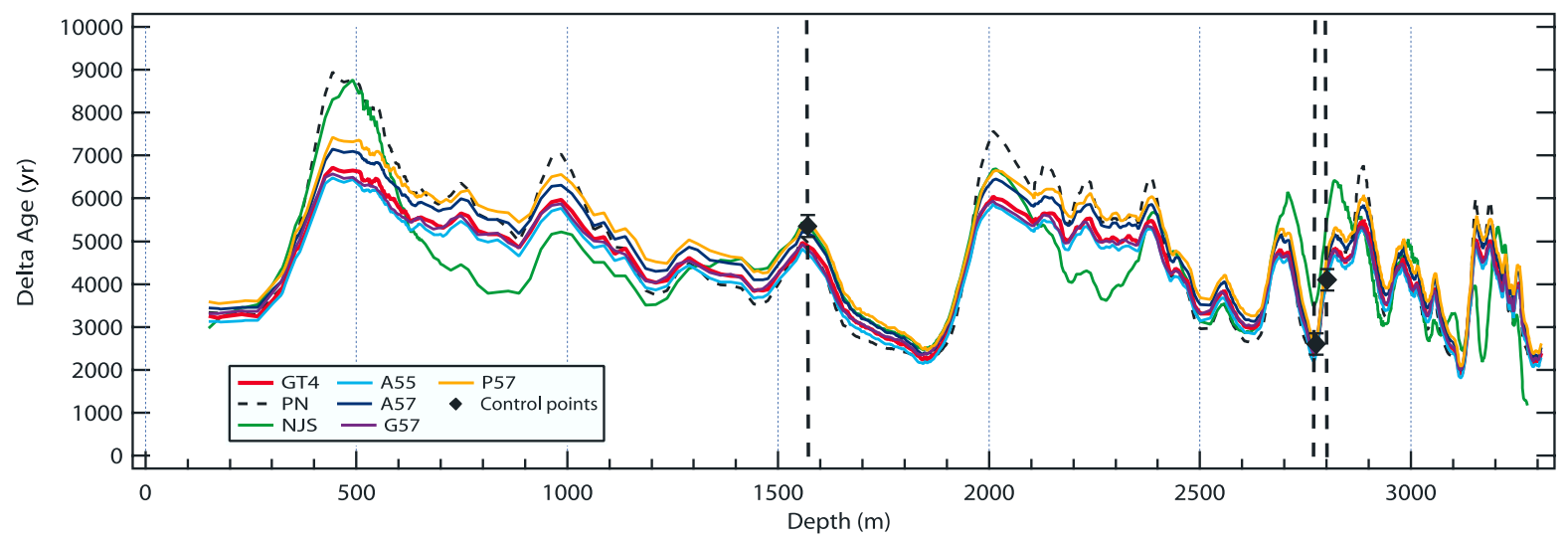

Figure 3. (a) Departure of the different Vostok timescales with regards to the reference GT4 chronology for the ice age. (b) Comparison of the $\Delta$ age versus depth for the seven different scenarios used in this study (PN timescale black dashed line; NJS green line, A55 light blue line, A57 dark blue line, G57 purple line, and P57 orange line). The black diamonds represent estimates deduced from permanent gas isotopes measurements with their error bars [Caillon et al., 2001, 2003b].

during glacial times [Barnola et al., 1991]) partly dampened the true atmospheric $\mathrm{CH}_{4}$ fluctuations, the $\mathrm{D} / \mathrm{O}$ structure in the signal still shows up as a strong component in the $\mathrm{CH}_{4}$ spectrum. Assuming that such relationship held for earlier times, our extended Vostok record indicates that highfrequency northern hemisphere climate variability characterized the climate system during all climatic cycles. In this sense, we are using $\mathrm{CH}_{4}$ as a proxy for northern hemisphere temperature fluctuations.

[13] The atmospheric $\mathrm{CH}_{4}$ burden is naturally controlled by tropical wetlands [Chappellaz et al., 1993b; Fung et al., 1991]. A recent evaluation of the average $\mathrm{CH}_{4}$ amplitude during D/O events [Flückiger et al., 2004] indicates a strong relationship with low latitude summer insolation, thus favoring a dominant role of the subtropical to tropical regions in the $\mathrm{CH}_{4}$ budget. Indeed, these regions encounter high-frequency climate variability, as shown by the Chinese loess, stalagmite $\delta^{18} \mathrm{O}$ records [Chen et al., 1996; Wang et al., 2001] or by oceanic records from the Arabian Sea or Pacific Ocean [Hendy and Kennett, 1999; Hendy et al., 2002; Schulz et al., 1998; Voelker and Workshop Participants, 2002]. The strong precessional component of the spectrum in our signal gives additional support to this finding.

[14] On the other hand, the high-latitude dynamics associated with the strengthening/weakening of the global thermohaline circulation, driving freezing/thawing extent and amplitude of discontinuous permafrost, could have also contributed to the millennial variability in the $\mathrm{CH}_{4}$ signal. Recent studies on the interhemispheric $\mathrm{CH}_{4}$ gradient [Brook et al., 2000; Dällenbach et al., 2000] suggest that even if the tropics remained the major contributor to the global $\mathrm{CH}_{4}$ budget during glacial periods, the higher $\mathrm{CH}_{4}$ concentration during the warm $\mathrm{D} / \mathrm{O}$ events could be caused by higher source strength at $\mathrm{mid} / \mathrm{high}$ northern latitudes. Other possible contribution to the $\mathrm{CH}_{4}$ budget could also be found through clathrate degassing [Kennett et al., 2000]. As pointed out by Flückiger et al. [2004], it is still not possible to draw definitive conclusions as to where the $\mathrm{CH}_{4}$ variability mainly originated from and which climatic mechanisms or feedbacks could drive these fluctuations.

\section{Leads and Lags Between $\mathrm{CH}_{4}$ and Vostok Temperature}

\subsection{Age Scale and Uncertainty}

[15] The accuracy of comparing climate signals recorded respectively in the gas bubbles and in the ice essentially depends on the uncertainty in the age and $\Delta$ age calculations. The ice core chronology appears crucial on this regard because it is linked with the accumulation rate, which is among the parameters needed to calculate $\Delta$ age. To inves- 
Table 2. Summary of the Different Ice and Gas Chronologies Used in This Study for the Sensitivity Experiment ${ }^{\mathrm{a}}$

\begin{tabular}{|c|c|c|c|c|c|c|}
\hline \multirow[b]{2}{*}{$\begin{array}{l}\text { Sensitivity } \\
\text { Scenarios } \\
\end{array}$} & \multicolumn{3}{|c|}{ Reference Ice Chronology } & \multicolumn{3}{|c|}{ Parameterization of the Densification Model } \\
\hline & Name & Method & Source & $\begin{array}{c}\text { Surface } \\
\text { Temperature, } \\
{ }^{\circ} \mathrm{C} \\
\end{array}$ & Physics of the Firn & $\begin{array}{c}\text { Source of Densification } \\
\text { Model } \\
\text { Adaptation }\end{array}$ \\
\hline $\mathrm{PN}$ & $\mathrm{PN}$ & $\begin{array}{l}\text { glaciological inversion plus } \\
\text { chronological constraints }\end{array}$ & Parrenin et al. [2001] & -55 & classic & Barnola et al. [1991] \\
\hline NJS & NJS & $\delta^{18} \mathrm{O}_{\mathrm{atm}}$ plus orbital tuning & Shackleton [2000] & -55 & classic & Barnola et al. [1991] \\
\hline GT4 & GT4 & glaciological model & Petit et al. [1999] & -55 & classic & Barnola et al. [1991] \\
\hline P57 & GT4 & glaciological model & Petit et al. [1999] & -57 & classic & Barnola et al. [1991] \\
\hline A55 & GT4 & glaciological model & Petit et al. [1999] & -55 & $\begin{array}{l}\text { new physical parameterization } \\
\text { of the densification process }\end{array}$ & Arnaud et al. [2000] \\
\hline A57 & GT4 & glaciological model & Petit et al. [1999] & -57 & same as A55 & Arnaud et al. [2000] \\
\hline G57 & GT4 & glaciological model & Petit et al. [1999] & -57 & same as A55 plus heat diffusion & Goujon et al. [2003] \\
\hline
\end{tabular}

${ }^{a}$ The $\Delta$ age calculations (i.e., the gas age chronologies) are based on the densification model originally developed by [Barnola et al., 1991], forced by the surface temperature deduced from the $\delta D$ signal using the $\delta D$-T slope of $6.04 /{ }^{\circ} \mathrm{C}$ (taking into account a correction between the surface and the inversion layer and the variation of the isotopic composition of the water source for past temperatures [Jouzel et al., 2003]) and by the accumulation rate based on $\delta D$ [Barnola et al., 1991], except for the PN and NJS gas chronologies which have their own prescribed temperature and accumulation (see Parrenin et al. [2001] and Shackleton [2000], respectively).

tigate this issue we conducted sensitivity tests using three different ice chronologies and five different estimates of $\Delta$ age based on various parameterizations in the densification model used here (Figure 3 and Table 2).

[16] As far as the ice chronologies are concerned, their deviation with respect to GT4 can reach as much as $20 \mathrm{kyr}$ (Figure 3a, for more details about the different chronologies see Parrenin et al. [2001], Pépin et al. [2001], Petit et al. [1999], and Watanabe et al., 2003]).

[17] The differences between $\Delta$ ages calculated with the various scenarios are significant (Figure $3 b$ ). The largest difference lies in full glacial conditions (up to $2.5 \mathrm{kyr}$ ) whereas warm periods show a reduced discrepancy (less than 800 years); the deglaciations are associated with comparable $\Delta$ ages whatever the chronology considered.

[18] Indeed, $\Delta$ ages can be evaluated at Vostok through permanent gas isotope anomalies $\left(\delta^{15} \mathrm{~N}, \delta^{40} \mathrm{Ar}\right)$ recording surface temperature or accumulation changes which then affect the firn thickness and/or generate a thermal anomaly (see Caillon et al. [2001] for further discussions). Such constraints are only available at the MIS $5 \mathrm{~d} / 5 \mathrm{c}$ transition (110 kyr BP), at the start of termination III (240 kyr BP [Caillon et al., 2003b]) and at the MIS 7.5 optimum. These independent $\Delta$ age estimates agree well with all the $\Delta$ age estimates given by the models (Figure $3 b$ ). The maximum difference obtained between both approaches happens at $1570 \mathrm{~m}$ of depth; a $\Delta$ age of $5350 \pm 250$ years is given by $\delta^{15} \mathrm{~N}$ measurements whereas the modeled $\Delta$ ages range from 4700 to 5360 years. The underestimated ages come from PN, GT4, G57 and A55 (Table 2 for the definition of scenarios). For the two other $\Delta$ age estimates (at $2775.75 \mathrm{~m}$, $\Delta \mathrm{age}=2600 \pm 250$ years and at $2802 \mathrm{~m}, \Delta \mathrm{age}=4100 \pm$ 250 years) most modeled $\Delta$ age are within errors of the $\delta^{40} \mathrm{Ar}$ based estimate constraint, except for the NJS chronology and the PN chronology at $2802 \mathrm{~m}$ of depth. Overall, this comparison indicates that the modeled $\Delta$ ages are correct to within a few centuries where permanent gas estimates are available. Unfortunately, the lack of independent estimates from gas isotopes during MIS 2, 3 and 6 (where differences between models are the most significant) does not yet allow picking up the most probable scenario of $\Delta$ ages.

[19] Recently, ages at Vostok were evaluated against the Byrd $\mathrm{CH}_{4}$ and $\delta^{18} \mathrm{O}$ records, pointing out that the surface temperature changes deduced from water isotopes were more probable than some borehole temperature interpretation [Blunier et al., 2004]. The Vostok "experimental" $\Delta$ ages thus inferred from Byrd range between $\sim 4.5$ and $\sim 6 \mathrm{kyr}$ for Vostok depths between 500 and $750 \mathrm{~m}$. In our case, this evaluation would tend to favor the scenarios GT4, G57, A55 and NJS.

\subsection{Leads and Lags}

[20] The Greenland/Byrd-record comparison shows that during major climatic events of the last glacial, Antarctic temperature rises when Greenland experiences a stadial event and decreases at the time of abrupt Greenland warming [Blunier and Brook, 2001; Blunier et al., 1998]. This expression of the so-called "bipolar seesaw" shows up in a phase comparison between the two records as an apparent lead of Antarctica on Greenland climate, by 1.5 to $3 \mathrm{kyr}$. As initiated by Bender et al. [1994] a bipolar comparison can also be produced using Vostok data over the last glacial, but it is affected by the $\Delta$ age uncertainty.

[21] In order to determine leads and lags between $\mathrm{CH}_{4}$ and Vostok Antarctic temperature at different timescales and taking into account the different $\Delta$ age scenarios (Table 2), we apply a multiscale lag regression method (detailed in Appendix A) where maximum correlation between the two signals is determined within a given time window by varying the time axis of one variable with respect to the other. The method is applied to each ice chronology and $\Delta$ age scenario, providing an optimal time lag and correlation coefficient in each case (Figures 4 and 5). The results presented here were tested using two different approaches that produced similar results (see Appendix A). For clarity, Figures 4,5 , and 6 only present results obtained with the square correlation $\left(R^{2}\right)$ maximization method. Several time windows $(400,200,100,50,25$ and $12 \mathrm{kyr})$ were used in order to investigate leads and lags over different timescales. Where no estimate of the time lag or correlation coefficient is provided (Figures 4, 5, and 6), the maximum correlation was reached on the edge of the time window, and therefore discarded (see Appendix A for more details).

[22] Several interesting observations can be made from this analysis. First, time windows between 50 and $400 \mathrm{kyr}$ all indicate a coherent lag of $\mathrm{CH}_{4}$ versus Antarctic temper- 


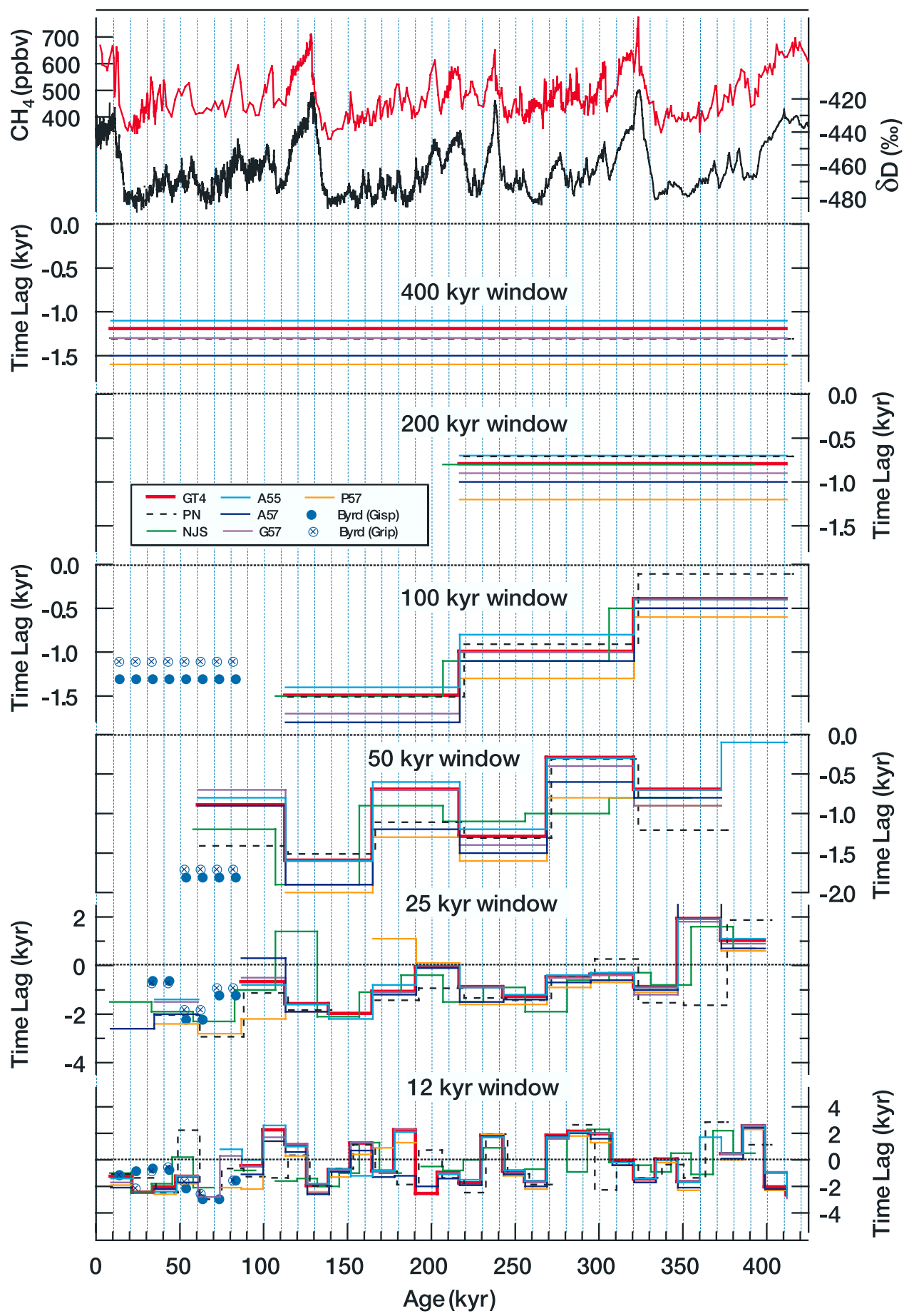

Figure 4. Leads and lags resulting from the correlation analysis between $\mathrm{CH}_{4}$ and deuterium (raw data are displayed on the top panel) using the multiscale lag regression method. The window sizes used for the Byrd core are slightly smaller than for Vostok because of the length of the initial series (80, 40, 20 and $10 \mathrm{kyr}$ ). The two chronologies used for Byrd are tied to GRIP (blue open circle) or GISP2 (solid blue circle) core reference timescales [from Blunier and Brook, 2001].

ature ranging from 100 to 2100 years (Figure 4, mean value of 900 to 1300 years depending on the time window considered). The 12- and 25-kyr windows show much more variability in the phase relationship at different time periods and depending on the chronology used. Similar conclusions can be drawn for the correlation coefficient (Figure 5).
[23] Figure 4 provides three major features on the $\mathrm{CH}_{4} /$ Antarctic temperature phase relationship:

[24] 1. $\mathrm{A} \mathrm{CH}_{4}$ time lag between 700 and 1600 years on the scale of two or four climatic cycles (200- and 400-kyr window); this time lag is mostly forced by the variance of both signals linked with terminations. A similar feature was 


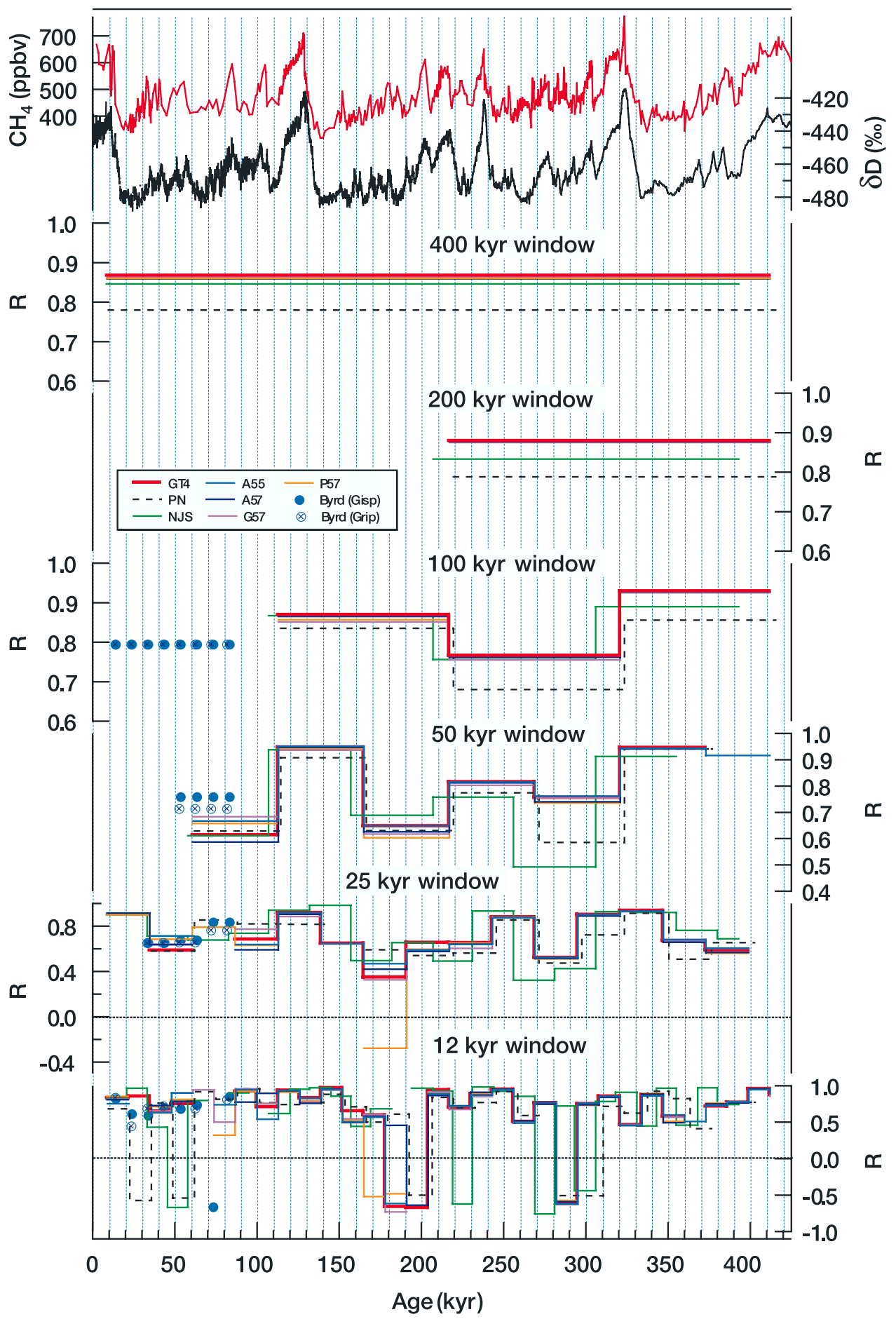

Figure 5. Same as Figure 4 but for the correlation coefficient $R$.

observed during termination I where Antarctic temperature starts to raise about 1000 years before the $\mathrm{CH}_{4}$ early increase and where the Younger Dryas/Preboreal $\mathrm{CH}_{4}$ increase takes place when Antarctica nearly ends its deglacial warming [Blunier et al., 1998]. This also confirms the general feature of deglacial events considered by Petit et al. [1999].

[25] 2. With time windows of 100 and $50 \mathrm{kyr}$, a significant decrease of the $\mathrm{CH}_{4}$ lag with time is observed; in addition within the 50-kyr windows, the first halves of glaciations reveal a smaller lag than the second halves. There are three possible explanations to such feature: a climatic mechanism varying bipolar energy exchanges in relation with ice sheet extents, an artifact due to smaller amount of captured variability for both $\mathrm{CH}_{4}$ and Antarctic isotope with increasing time, especially during MIS 10 , or a variable bias in the ice chronology possibly due to a badly estimated accumulation rate upstream from Vostok or due to ice flow. This last explanation can a priori be discarded because the decreased time lag trend appears for all chro- 


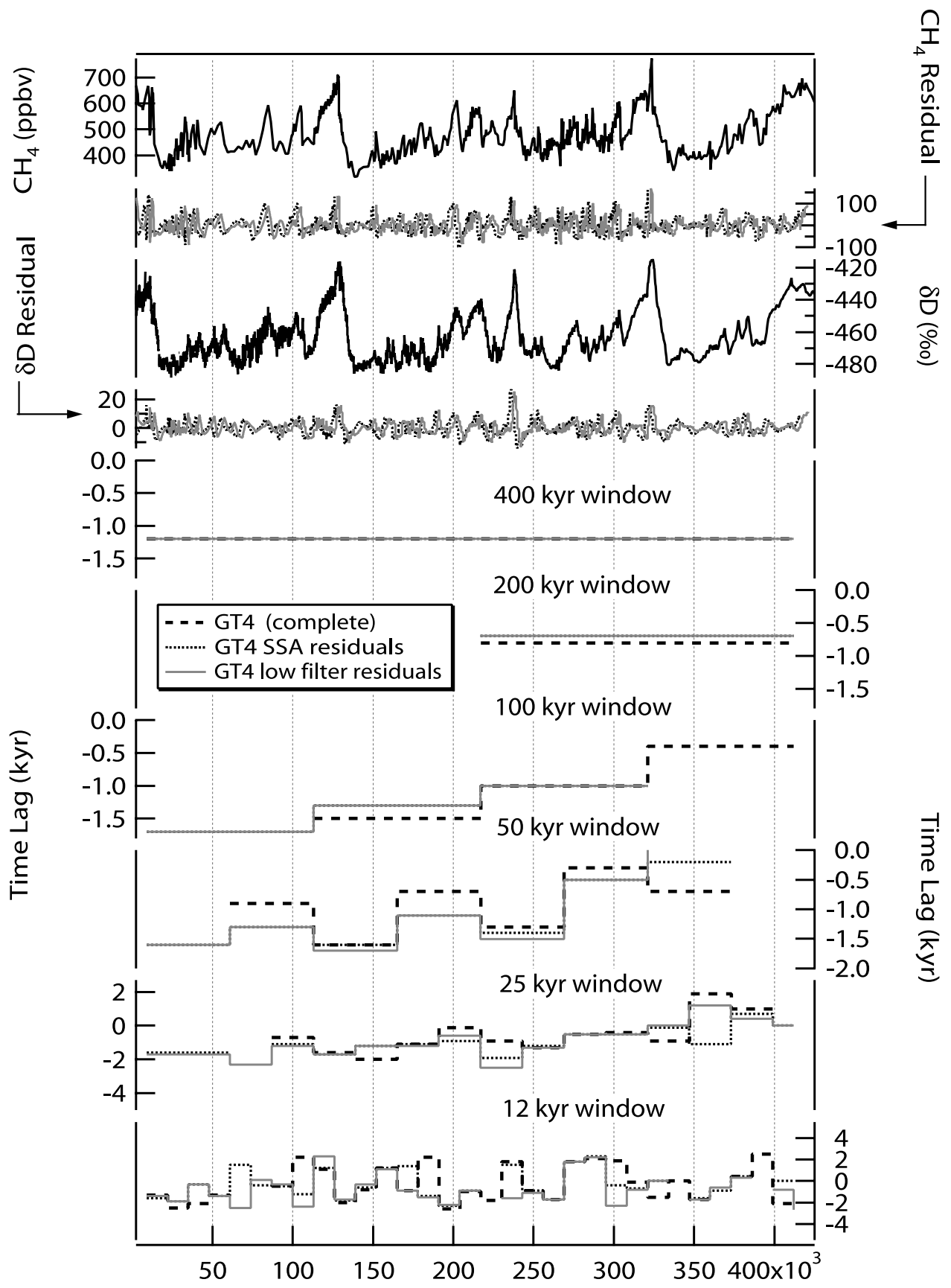

Age (kyr)

Figure 6. Leads and lags resulting from the correlation analysis between residuals of $\mathrm{CH}_{4}$ and deuterium records after removal of the Milankovich frequencies. (Raw data and residuals series obtained using the two different methods are displayed on the top panel.) The dashed line represents the results presented on Figure 4 for the GT4 timescale and obtained on the complete initial series.

nologies and especially for the NJS chronology, which is orbitally tuned (Figure 4).

[26] 3. The 25- and 12-kyr time windows show on average a reduced $\mathrm{CH}_{4}$ lag than longer time windows. This arises from frequent jumps between $\mathrm{CH}_{4}$ lags and $\mathrm{CH}_{4}$ leads over Vostok temperature; the lengths of the correlation windows being close to the duration of rapid events, best signal coherence can be found either by increasing or decreasing the relative age of the $\mathrm{CH}_{4}$ record with respect to the temperature record, with the possibility of highest $R^{2}$ through anticorrelation of the two signals (Figure 5). This phenomenon is even more obvious for the 12-kyr window and reveals the limit of the correlation method used here, as detailed in Appendix A.

[27] The $\mathrm{CH}_{4}$ /temperature relationship deduced from the Byrd Antarctic ice core, with its better precision on $\Delta$ age 
estimates $(\sim 1$ order of magnitude better than Vostok) provides an independent check of these findings over the last $90 \mathrm{kyr}$, through our multiscale lag regression method. The Byrd phasing also reveals a consistent lag of $\mathrm{CH}_{4}$ versus Byrd Antarctic temperature and thus gives support to our analyses; but the magnitude of the lag is slightly different compared to Vostok (Figures 4 and 5). Considering two different Byrd chronologies [Blunier and Brook, 2001] does not affect significantly this observation. The worst agreement between Vostok and Byrd lag estimates arises for the 50-kyr window covering MIS 4 and 5, with a difference between both estimates of about 600 years. This is the time period where the available Vostok $\mathrm{CH}_{4}$ record provides a poor time resolution (mean of 1800 years with a range between 500 and 2800 years) and does not resolve all the variability observed in higher resolution records such as GISP2, Byrd and Taylor Dome.

[28] To investigate more specifically the leads and lags on rapid events, we applied the multiscale regression method on the residuals of the $\mathrm{CH}_{4}$ and $\delta D$ series, after removal of the variability linked with orbital frequencies. Two methods were used: (1) using a low-pass filter and (2) reconstructing the Vostok series after deconvolution and removal of the first four principal frequencies for each signal using the Singular Spectrum Analysis method ((SSA) [Ghil et al., 2002]). Using the first method ensures the removal of a similar frequency on each time series, but possibly not all the orbital variability, whereas the second method ensures the cutting of all the orbital frequencies but possibly with different spectral signature for each time series. We used the GT4 age scale, but a similar conclusion would be drawn from other chronologies. The leads and lags resulting from both approaches are coherent and agree well with those for the unfiltered original data, as illustrated in Figure 6. This confirms that much of the lead/lag relationship pointed out with the full records is linked with rapid Dansgaard/ Oeschger-type events.

[29] Overall, although the magnitude of the lag is still a matter for discussions and improvements, our analyses of the temporal relationship between atmospheric $\mathrm{CH}_{4}$ and Antarctic temperature supports a systematic apparent lead of the latter in the course of the last four climatic cycles, both at low and high frequencies. As $\mathrm{CH}_{4}$ has been shown to follow Greenland temperature changes at the scale of a few decades over the last glaciation and deglaciation [Severinghaus and Brook, 1999; Severinghaus et al., 1998], our observation implies that a sustained climatic mechanism (or a suite of them) drove the sequence of rapid events consistently throughout the last $420 \mathrm{kyr}$. Arguing for instance about the relative contribution of the thermohaline circulation and tropical water cycle feedbacks is beyond the scope of our findings. As already pointed out by Caillon et al. [2003a], the phase relationship between the two poles cannot be considered diagnostic of the location of origin of millennialscale climate changes, nor the physical mechanism involved. However, it provides constraints to test the validity of global climate models that simulate the sequence of events.

\section{Conclusions}

[30] The improved temporal resolution of our Vostok $\mathrm{CH}_{4}$ record corroborates prior findings that the high present-day
$\mathrm{CH}_{4}$ mixing ratio is unprecedented during the last $420 \mathrm{kyr}$ and confirms the strong imprint of orbital frequencies in this biogeochemical signal. Most importantly, it reveals a $\mathrm{CH}_{4}$ high-frequency variability over the past four climatic cycles, which had been previously depicted by Greenland records only over the last climatic cycle. This suggests that the climate system not only behave as an oscillator over long time periods (i.e., orbital frequencies) but also shows up with a coherent and cyclic high-frequency variability in the course of each climate cycle.

[31] Phase correlation analyses between $\mathrm{CH}_{4}$ and Vostok temperature indicate a systematic apparent lag of $\mathrm{CH}_{4}$ by $\sim 1100 \pm 200$ years, similar to the one observed during the last glacial period and expressing the so-called "bipolar seesaw." This result has been tested against different ice and trapped gas chronologies, and appears robust for long time windows (200 kyr to $50 \mathrm{kyr}$ ). Over shorter time windows (25 kyr and $12 \mathrm{kyr}$ ), the $\mathrm{CH}_{4}-\delta D$ phase correlation shows much more variability as the window length gets closer to the duration of events. Overall, the improved Vostok $\mathrm{CH}_{4}$ profile and its correlation analysis with Vostok temperature, either with the full record or with residuals deconvolved from orbital frequencies point toward the existence of internal climatic mechanisms that acted as high-frequency pacemakers of glacial climate variability over at least the last four glaciations. Although the exact mechanisms remain unclear and unconstrained through our approach, it represents a challenging observation for future climate modeling efforts.

[32] On the ice core side, the next step will consist of (1) decreasing the noise of the $\mathrm{CH}_{4}$ and Antarctic temperature records, especially on the basis of the new EPICA/Dome C ice core, (2) improving the quantitative estimate of the $\mathrm{CH}_{4}$ lag with respect to temperature, using chronological constraints between Vostok and Dome C, and (3) extending back in time our observations into epochs when the 40-kyr period dominated the Earth's climate variability, again with the new Dome C ice core.

\section{Appendix A: Multiscale Lag Regression Between Two Time Series}

[33] The starting assumption of the method is that a time series $Y(t)$ is obtained from a reference $X(t)$ by a constant linear transform and random phase shifts. Hence a global coherence and phase analysis between the series $X(t)$ and $Y(t)$ might be quite irrelevant because the phase lags are certainly not constant through time (and can change signs). The general idea is to cut each time series into nonoverlapping intervals, and perform a phase analysis on each interval. Borrowing the concept of multiscale analysis from wavelet transforms, we vary the length of the intervals with a geometrical sequence. Thus slow covariance will be captured by large scales, and fast covariance by small scales. For instance, it is not a priori clear that temperature and $\mathrm{CH}_{4}$ share the same relationship on glacial to interglacial cycles, and rapid events such as the DansgaardOeschger oscillations. Thus, using a multiscale analysis is useful to investigate whether the $\mathrm{CH}_{4}$-temperature relationship comes from one or several biophysical processes. The stability of the results will be investigated by using different chronologies for the time series. 
[34] On each time interval $T$, we determine an optimal phase lag between $X(t)$ and $Y(t+\tau)$ by maximizing the square correlation $R^{2}$ between the two sub time series:

$$
R(\tau)=\frac{\sum_{t \in T} X(t+\tau) Y(t)}{N \sigma_{X} \sigma_{Y}} .
$$

Here $\tau$ varies between -30 and 30 time steps, corresponding to a lag range of $-3 \mathrm{kyr}$ to $3 \mathrm{kyr}$. A more rigorous way of optimizing the lag is to make a linear regression of $X(t)$ and $Y(t)$ on each interval $T$, with varying phase lags, compute a likelihood function of these regressions $\Lambda$ :

$$
\Lambda(a, b, \tau)=\frac{1}{\sigma_{D}^{N}} \exp -\frac{\sum_{t \in T} D(t)^{2}}{2 \sigma_{D}^{2}},
$$

where $N$ is the number of data points in the interval $T, D(t)$ is the residual of the linear regression between $Y(t)$ and $X(t+\tau)$ in $T$ :

$$
D(t)=Y(t)-a X(t+\tau)-b,
$$

and $\sigma_{D}^{2}$ is the variance of $D(t)$. Then we compute the maximum (log) likelihood over the phase lag range $\tau$ and regression parameters $a$ and $b$. Both correlation and likelihood approaches give similar results (albeit not strictly identical) and thus we will mention the local correlation optimization because it is more straightforward to interpret.

[35] It is important to note that the optimum correlation (or likelihood) should be reached within the lag range, and not on the edge of a given lag interval, to ensure that the maximized function $\left(R^{2}\right.$ or $\left.\Lambda\right)$ is concave. Otherwise, the maximum might depend on the length of the scale, which is undesirable. Thus, whenever a maximum was reached on the edge of a lag interval, we discarded the corresponding scale and time interval, and rejected the hypothesis that there is a local linear relation between the two time series.

[36] Sensitivity tests made using lag intervals of different length shows that the choice of the lag interval can also affect the optimum correlation (or likelihood, not shown). Hence we advocate the use of lag intervals that are no larger than one quarter of the scale, especially in the presence of large noise levels and sampling heterogeneity between the two time series. All the lag computations where run with Scilab (available at www.scilab.org), and the routines can be obtained from the authors.

[37] Acknowledgments. The Vostok ice coring program is a multiyear joint effort between Russia, France and the USA. We thank ice drillers and all participants in the fieldwork and ice sampling, the Russian Antarctic Expeditions (RAE), the Institut Français Paul Emile Victor (IPEV) and the Office of Polar Programs (NSF) for logistic support. This work is a contribution to the EC project Pole-Ocean-Pole (EVK2-2000-22067). Additional financial support in France was provided by the Programme National d'Etudes de la Dynamique du Climat (INSU-CNRS). The US National Science Foundation, Office of Polar Programs, provided financial support for the WSU portion of the project. We are indebted to Susan Harder who contributed significantly to the $\mathrm{CH}_{4}$ measurements at WSU. We thank Jean Jouzel, Valérie Masson-Delmotte and Amaëlle Landais for fruitful discussion and comments. We are deeply grateful to Todd Sowers, Bernhard Stauffer and an anonymous reviewer for constructive and helpful reviews.

\section{References}

Arnaud, L., J.-M. Barnola, and P. Duval (2000), Physical modeling of the densification of snow/firn and ice in the upper part of polar ice sheets, in Physics of Ice Core Records, edited by T. Hondoh, pp. 285-305, Hokkaido Univ. Press, Sapporo, Japan.

Barnola, J. M., D. Raynaud, Y. S. Korotkevitch, and C. Lorius (1987), Vostok ice core provides 160,000 -year record of atmospheric $\mathrm{CO}_{2}$, Nature, 329, 408-414.

Barnola, J.-M., P. Pimienta, D. Raynaud, and Y. S. Korotkevich (1991), $\mathrm{CO}_{2}$-climate relationship as deduced from the Vostok ice core: A reexamination based on new measurements and on a re-evaluation of air dating, Tellus, Ser. B, 43, 83-90.

Bassinot, F. C., L. D. Labeyrie, E. Vincent, X. Quidelleur, N. J. Shackleton, and Y. Lancelot (1994), The astronomical theory of climate and the age of the Brunhes-Matuyama magnetic reversal, Earth Planet. Sci. Lett., 126, 91-108.

Bender, M., T. Sowers, M.-L. Dickson, J. Orchardo, P. Grootes, P. A. Mayewski, and D. A. Meese (1994), Climate correlations between Greenland and Antarctica during the past 100,000 years, Nature, 372, 663-666.

Berner, W., B. Stauffer, and H. Oeschger (1978), Past atmospheric composition and climate, gas parameters measured on ice cores, Nature, 276, $53-55$.

Blunier, T., and E. Brook (2001), Timing of millenial-scale climate change in Antarctica and Greenland during the last glacial period, Science, 291, $109-112$.

Blunier, T., J. Chappellaz, J. Schwander, B. Stauffer, and D. Raynaud (1995), Variations in atmospheric methane concentration during the Holocene epoch, Nature, 374, 46-49.

Blunier, T., et al. (1998), Asynchrony of Antarctic and Greenland climate change during the last glacial period, Nature, 394, 739-743.

Blunier, T., J. Schwander, J. Chappellaz, F. Parrenin, and J.-M. Barnola (2004), What was the surface temperature in central Antarctica during the last glacial maximum?, Earth Planet. Sci. Lett., 218, 379-388, doi:10.1016/S0012-821X (03)0672-1.

Brook, E. J., T. Sowers, and J. Orchardo (1996), Rapid variations in atmospheric methane concentration during the past 110,000 years, Science, 273, 1087-1091.

Brook, E. J., J. Severinghaus, S. Harder, and M. Bender (1999), Atmospheric methane and millennial-scale climate change, in Mechanisms of Global Climate Change at Millennial Time Scales, Geophys. Monogr. Ser., vol. 112, edited by P. U. Clark, R. S. Webb, and L. Keigwin, pp. 165-176, AGU, Washington, D. C.

Brook, E. J., S. Harder, J. Severinghaus, E. Steig, and C. M. Sucher (2000), On the origin and timing of rapid changes in atmospheric methane during the last glacial period, Global Biochem. Cycles, 14(2), 559-572.

Caillon, N., J. P. Severinghaus, J.-M. Barnola, J. Chappellaz, J. Jouzel, and F. Parrenin (2001), Estimation of temperature change and of gas age-ice age difference, 108 kyr B.P., at Vostok, Antarctica, J. Geophys. Res., 106(D23), 31,893-31,901.

Caillon, N., J. Jouzel, S. J. P. J. Chappellaz, and T. Blunier (2003a), A novel method to study the phase relationship between Antarctic and Greenland climate, Geophys. Res. Lett., 30(17), 1899, doi:10.1029/2003GL017838.

Caillon, N., J. P. Severinghaus, J. Jouzel, J.-M. Barnola, J. Kang, and V. Y. Lipenkov (2003b), Timing of atmospheric $\mathrm{CO}_{2}$ and Antarctic temperature changes across termination III, Science, 299, 1728-1731.

Chappellaz, J., J.-M. Barnola, D. Raynaud, Y. S. Korotkevich, and C. Lorius (1990), Ice-core record of atmospheric methane over the past 160,000 years, Nature, 345, 127-131.

Chappellaz, J., T. Blunier, D. Raynaud, J. M. Barnola, J. Schwander, and B. Stauffer (1993a), Synchronous changes in atmospheric $\mathrm{CH}_{4}$ and Greenland climate between 40 and 8 Kyr BP, Nature, 366, 443-445.

Chappellaz, J., I. Y. Fung, and A. Thompson (1993b), The atmospheric $\mathrm{CH}_{4}$ increase since the Last Glacial Maximum (1) Source estimates, Tellus, Ser. $B, 45,228-241$.

Chappellaz, J., T. Blunier, S. Kints, A. Dällenbach, J.-M. Barnola, J. Schwander, D. Raynaud, and B. Stauffer (1997), Changes in the atmospheric $\mathrm{CH}_{4}$ gradient between Greenland and Antarctica during the Holocene, J. Geophys. Res., 102(D13), 15,987-15,997.

Chen, F. H., J. Bloemendal, J. M. Wang, J. J. Li, and F. Oldfield (1996), High-resolution multi-proxy climate records from Chinese loess: Evidence for rapid climatic changes over the last $75 \mathrm{kyr}$, Palaeogeogr. Palaeoclimatol. Palaeoecol., 30, 323-335.

Dällenbach, A., T. Blunier, J. Flückiger, B. Stauffer, J. Chappellaz, and D. Raynaud (2000), Changes in the atmospheric $\mathrm{CH}_{4}$ gradient between Greenland and Antarctica during the last glacial and the transition to the Holocene, Geophys. Res. Lett., 27(7), 1005-1008.

Etheridge, D. M., L. P. Steele, R. L. Langenfelds, and R. J. Francey (1996), Natural and anthropogenic changes in atmospheric $\mathrm{CO}_{2}$ over the last 1000 years from air in Antarctic ice and firn, J. Geophys. Res., 101(D2), 4115-4128. 
Etheridge, D. M., L. P. Steele, R. J. Francey, and R. L. Langenfelds (1998), Atmospheric methane between 1000 A. D. and present: Evidence of anthropogenic emissions and climatic variability, J. Geophys. Res., 103(D13), 15,979-15,994.

Flückiger, J., A. Dällenbach, T. Blunier, B. Stauffer, T. Stocker, D. Raynaud, and J.-M. Barnola (1999), Variations in atmospheric $\mathrm{N}_{2} \mathrm{O}$ concentration during abrupt climatic changes, Science, 285, 227-230.

Flückiger, J., T. Blunier, B. Stauffer, J. Chappellaz, R. Spahni, K. Kawamura, J. Schwander, T. Stocker, and D. Dahl-Jensen (2004), $\mathrm{N}_{2} \mathrm{O}$ and $\mathrm{CH}_{4}$ variations during the last glacial epoch: Insight into global processes, Global Biogeochem. Cycles, 18, GB1020, doi:10.1029/2003GB002122.

Fung, I., J. John, J. Lerner, E. Matthews, M. Prather, L. P. Steele, and P. J. Fraser (1991), Three-dimensional model synthesis of the global methane cycle, J. Geophys. Res., 96, 13,033-13,065.

Ghil, M., et al. (2002), Advanced spectral methods for climatic time series, Rev. Geophys., 40(1), 1003, doi:10.1029/2000RG000092.

Goujon, C., J.-M. Barnola, and C. Ritz (2003), Modeling the densification of polar firn including heat diffusion: Application to close-off characteristics and gas isotopic fractionation for Antarctica and Greenland sites., J. Geophys. Res., 108(D24), 4792, doi:10.1029/2002JD003319.

Hagelberg, T. K., G. Bond, and P. deMenocal (1994), Milankovitch band forcing of sub-Milankovicht climate variability during Pleistocene, Paleoceanography, 9(4), 545-558.

Hendy, I. L., and J. P. Kennett (1999), Latest Quaternary North Pacific surface-water responses imply atmosphere-driven climate instability, Geology, 27(4), 291-294.

Hendy, I. L., J. P. Kennett, E. B. Roark, and B. L. Ingram (2002), Apparent synchroneity of submillennial scale climate events between Greenland and Santa Barbara basin, California from 30-10 ka, Quat. Sci. Rev., 21, 1167-1184

Intergovernmental Panel on Climate Change (IPCC) (2001), The carbon cycle and atmospheric carbon dioxide, in Climate Change 2001: The Scientific Basis, edited by J. T. Houghton et al., pp. 185-237, Cambridge Univ. Press, New York.

Johnsen, S. J., et al. (1997), The $\delta^{18} \mathrm{O}$ record along the Greenland Ice Core Project deep ice core and the problem of possible Eemian climatic instability, J. Geophys. Res., 102(C12), 26,397-26,410.

Jouzel, J., et al. (1993), Extending the Vostok ice-core record of palaeoclimate to the penultimate glacial period, Nature, 364, 407-411.

Jouzel, J., J. R. Petit, R. Souchez, N. I. Barkov, V. Y. Lipenkov, D. Raynaud, M. Stievenard, N. I. Vassiliev, V. Verbeke, and F. Vimeux (1999), More than 200 meters of lake ice above subglacial lake Vostok, Antarctica, Science, 286, 2138-2141.

Jouzel, J., F. Vimeux, N. Caillon, G. Delaygue, G. Hoffmann, V. MassonDelmotte, and F. Parrenin (2003), Magnitude of the isotope/temperature scaling for interpretation of central Antarctic ice cores, J. Geophys. Res., 108(D12), 4361, doi:10.1029/2002JD002677.

Kennett, J. P., K. G. Cannariato, I. L. Hendy, and R. J. Behl (2000), Carbon isotopic evidence for methane hydrate instability during quaternary interstadials, Science, 288, 128-133.

Mann, M. E., and J. M. Lees (1996), Robust estimation of background noise and signal detection in climatic time series, Clim. Change, 33, 409-445.

Mazaud, A., F. Vimeux, and J. Jouzel (2000), Short fluctuations in Antarctic isotope records: A link with cold events in the North Atlantic?, Earth Planet. Sci. Lett., 142, 19-27.

Parrenin, F., J. Jouzel, C. Waelbroeck, C. Ritz, and J.-M. Barnola (2001), Dating of the Vostok ice core by an inverse method, J. Geophys. Res., 106(D23), 31,837-31,851.

Pépin, L., D. Raynaud, J.-M. Barnola, and M. F. Loutre (2001), Hemispheric roles of climate forcings during glacial-interglacial transitions as deduced from the Vostok record and LLN-2D model experiments, J. Geophys. Res., 106(D23), 31,885-31,892.

Petit, J. R., et al. (1999), Climate and atmospheric history of the past 420,000 years from the Vostok ice core, Antarctica, Nature, 399, 429-436.

Raynaud, D., J. Chappellaz, J. M. Barnola, Y. S. Korotkevich, and C. Lorius (1988), Climatic and $\mathrm{CH}_{4}$ cycle implications of glacial-interglacial $\mathrm{CH}_{4}$ change in the Vostok ice core, Nature, 333, 655-657.

Raynaud, D., M.-F. Loutre, C. Ritz, J. Chappellaz, J.-M. Barnola, J. Jouzel, V. Y. Lipenkov, J.-R. Petit, and F. Vimeux (2002), Marine Isotope Stage (MIS) 11 in the Vostok ice core: $\mathrm{CO}_{2}$ forcing and stability of East Antarctica, in Earth's Climate and Orbital Eccentricity: The Marine Isotope Stage 11 Question, Geophys. Monogr. Ser., vol. 137, edited by A. W. Droxler, R. Z. Pore, and L. H. Burckle, pp. 27-40, AGU, Washington, D. C.

Schulz, H., U. von Rad, and H. Erlenkeuser (1998), Correlation between Arabian Sea and Greenland climate oscillations of the past 110,000 years, Nature, 393, 54-57.

Severinghaus, J. P., and E. Brook (1999), Abrupt climate change at the end of the last glacial period inferred from trapped air in polar ice, Science, 286, 930-934.

Severinghaus, J. P., T. Sowers, E. Brook, R. Alley, and M. Bender (1998), Timing of abrupt climate change at the end of the Younger Dryas interval from thermally fractionated gases in polar ice, Nature, 391, $141-$ 146.

Shackleton, N. J. (2000), The 100,000 year ice-age cycle identified and found to lag temperature, carbon dioxide, and orbital eccentricity, Science, 289, 1897-1902.

Sowers, T., E. Brook, D. Etheridge, T. Blunier, A. Fuchs, M. Leuenberger, J. Chappellaz, J.-M. Barnola, M. Wahlen, B. Deck, and C. Weyhenmeyer (1997), An interlaboratory comparison of techniques for extracting and analysing trapped gases in ice cores, J. Geophys. Res., 102(C12), 26,527-26,538.

Voelker, A. H. L., Workshop Participants (2002), Global distribution of centennial-scale records for Marine Isotope Stage (MIS) 3: A database, Quat. Sci. Rev., 21, 1185-1212.

Wang, Y. J., H. Cheng, R. L. Edwards, Z. S. An, J. Y. Wu, C.-C. Shen, and J. A. Dorale (2001), A high-resolution absolute-dated late Pleistocene monsoon record from Hulu cave, China, Science, 294, 2345-2348.

Watanabe, O., J. Jouzel, S. Johnsen, F. Parrenin, H. Shoji, and N. Yoshida (2003), Homogeneous climate variability across East Antarctica over the past three glacial cycles, Nature, 422, 509-512.

Yiou, P., J. Jouzel, S. Johnsen, and Ö. E. Rögnvaldsson (1995), Rapid oscillations in the Vostok and GRIP ice cores, Geophys. Res. Lett., 22(16), 2179-2182.

Yiou, P., F. Vimeux, and J. Jouzel (2001), Ice age variability from the Vostok deuterium and deuterium excess records, J. Geophys. Res., 106(D23), 31,875-31,884.

J. M. Barnola, J. Chappellaz, C. Goujon, and D. Raynaud, Laboratoire de Glaciologie et Géophysique de l'Environnement, CNRS-UJF, F-38402 St. Martin d'Hères, France.

E. Brook, Department of Geology, Washington State University, Vancouver, WA 98686, USA.

M. Delmotte and P. Yiou, Laboratoire des Sciences du Climat et de l'Environnement, CNRS-CEA 1572, CE Saclay L'Orme des merisiers, Bât 709, F-91191 Gif sur Yvette Cedex, France. (delmotte@1sce.saclay.cea.fr) V. I. Lipenkov, Arctic and Antarctic Research Institute, 199397 St. Petersburg, Russia. 